\title{
Management of pulmonary aspergillosis in AIDS: an emerging clinical problem
}

\author{
J J Keating, T Rogers, M Petrou, J D Cartledge, D Woodrow, M Nelson, D A Hawkins, \\ B G Gazzard
}

\begin{abstract}
Aims-To review the clinical, radiographic, and therapeutic features of 11 cases of respiratory Aspergillus infection in patients with AIDS.
\end{abstract}

Methods-All induced sputum and bronchoalveolar lavage samples obtained from HIV seropositive patients between January 1985 and March 1993 were analysed for Aspergillus species. Additionally, where appropriate, bronchial or renal biopsy specimens, or both, were taken before treatment had started.

Results-In 11 patients Aspergillus fumigatus was identified in alveolar samples obtained by sputum induction. This was confirmed by bronchoalveolar lavage in eight. Three patients had Aspergillus plaques in the trachea and bronchus, while a fourth patient had an aspergilloma. Risk factors for Aspergillus infection were present in all patients, including corticosteroid treatment in three cases and neutropenia in four, three of whom had received chemotherapy for Kaposi's sarcoma. Four patients had concomitant cytomegalovirus infection. Ten patients had a CD4 count of less than 50 cells $/ \mathrm{mm}^{3}$ while one patient had a disseminated $T$ cell lymphoma with a CD4 count of $242 \mathrm{cells} / \mathrm{mm}^{3}$. Of the three patients with samples obtained by sputum induction who did not undergo bronchoscopy, two had a normal chest $x$ ray picture and the third had a right lobar pneumonia complicating an aggressive lymphoma. All three were treated with itraconazole $200 \mathrm{mg}$ twice a day without further investigation.

Survival from the time of diagnosis of Aspergillus infection was short: seven patients died within six weeks, although only one death was directly attributed to pulmonary aspergillosis. At six monthly follow up, one patient, who initially had a positive Aspergillus culture from bronchial washings and a normal chest radiograph, developed a renal aspergilloma despite the disappearance of Aspergillus sp from the sputum.

Conclusion-Pulmonary aspergillosis is an important clinical problem in patients with AIDS with a CD4 count of less than 50 cells $/ \mathrm{mm}^{3}{ }^{3}$ Furthermore, patients with Aspergillus sp in sputum induction or bronchial washings may develop disseminated disease despite adequate treatment of the primary infection.

$(\mathcal{C}$ Clin Pathol 1994;47:805-809)

Pulmonary aspergillosis is rarely found in HIV seropositive patients compared with its prevalence in other conditions producing a similar degree of immunosuppression, such as organ transplantation, lymphoma, and leukaemia. ${ }^{1-5}$ However, these patients are more likely to have impaired phagocytic function because of drug treatment than patients with AIDS.

Although the diagnosis of pulmonary aspergillosis is initially suggested by a positive sputum culture, in immunocompetent people the presence of a few colonies of Aspergillus present on artificial culture media may only indicate harmless colonisation or contamination. In immunosuppressed patients the finding of Aspergillus in sputum may be more important, particularly when the growth is heavy and when the patient is neutropenic. ${ }^{6}$

Aspergillus may colonise the upper respiratory tract without causing disease, or it can cause a wide spectrum of clinical illness. This may be limited to the bronchi, with or without macroscopic plaques, or may be associated with local invasion of the lung, producing radiographic changes or with widespread dissemination of infection. ${ }^{26}$

Even though we have routinely cultured bronchoalveolar lavage and sputum induction specimens for fungi since 1985, we have only regularly detected Aspergillus in such specimens since 1992. We review the findings and clinical course of these patients.

\section{Methods}

Patients found to be HIV antibody positive had their personal details and subsequent clinical course recorded on the departmental computer. By comparing this record with that held within the Department of Mycology, of all patients having sputum induction or bronchioloalveolar lavage, a complete collection of those diagnosed with pulmonary aspergillosis was assured.

All patients fasted overnight before bronchoscopy or sputum induction. Contamination of the induced sputum specimen with oral debris was avoided by cleansing of the buccal mucosa, tongue, and gums with a 
Clinical details of patients studied

\begin{tabular}{|c|c|c|c|c|c|c|c|}
\hline $\begin{array}{l}\text { Case } \\
\text { No }\end{array}$ & AIDS & $\begin{array}{l}\text { Neutrophils } \\
10^{\circ} / l\end{array}$ & $\begin{array}{l}C D 4 \\
10^{9} / l\end{array}$ & Problems and antibiotic treatment & $\begin{array}{l}\text { Chest } x \text {-ray, } \mathrm{PaO}^{2} \text {, } \\
\text { bronchoscopy }\end{array}$ & $\begin{array}{l}\text { Antifungal } \\
\text { treatment }\end{array}$ & Outcome \\
\hline 1 & $4 \cdot 91$ & $0 \cdot 3$ & 35 & $\begin{array}{l}\text { Fever, dry cough, breathlessness, } \\
\text { Kaposi's sarcoma-treatment vincristine, } \\
\text { bleomycin. CMV of oesophagus: } \\
\text { azithromycin, septrin. }\end{array}$ & $\begin{array}{l}\text { Widespread infiltrate } \\
\mathrm{PO}_{2} 11 \cdot 2 \\
\text { Aspergillus plaques }\end{array}$ & $\begin{array}{l}\text { Itraconazole tablet } \\
400 \mathrm{mg} / \text { day }(6 / 52)\end{array}$ & $\begin{array}{l}\text { Died } 6 / 52 \text { : necropsy } \\
\text { sepsis, pulmonary } \\
\text { aspergillosis }\end{array}$ \\
\hline 2 & $5 \cdot 90$ & $4 \cdot 0$ & 50 & $\begin{array}{l}\text { Fever, dry cough. Kaposi's sarcoma- } \\
\text { treatment vincristine, bleomycin, } \\
\text { prednisolone } 40 \mathrm{mg} .7 \cdot 92 \text { Aspergillus and } \\
\text { Pseudomonas: teicoplanin, cefuroxime. }\end{array}$ & $\begin{array}{l}\text { Infiltrate } \\
\text { Bilateral } \mathrm{PO}_{2} 12 \cdot 4 \\
\text { Aspergillus plaques }\end{array}$ & $\begin{array}{l}\text { Itraconazole tablet } \\
400 \mathrm{mg} / \text { day }(1 / 52)\end{array}$ & $\begin{array}{l}\text { Died 1/52: } \\
\text { multisystem failure }\end{array}$ \\
\hline 3 & $8 \cdot 88$ & 0.5 & 30 & $\begin{array}{l}\text { Fever, dry cough tuberculosis/leishmaniasis, } \\
\text { cannabis smoker. } 8.89 \text { A fumigatus: isoniazid, } \\
\text { NA-stibogluconate. }\end{array}$ & $\begin{array}{l}\text { Hilar shadowing on } \\
\text { right } \\
\mathrm{PO}_{2} 8 \cdot 7 \\
\text { No plaques }\end{array}$ & $\begin{array}{l}\text { Itraconazole tablet } \\
400 \mathrm{mg} / \text { day }(6 / 52)\end{array}$ & $\begin{array}{l}\text { Dies } 12 / 12: \text { end stage } \\
\text { HIV disease }\end{array}$ \\
\hline 4 & $4 \cdot 92$ & $4 \cdot 0$ & 242 & $\begin{array}{l}\text { Dry cough, breathlessness, } \mathrm{T} \text { cell lymphoma } \\
\text { of gut, stage } 4 \mathrm{~B} \text {, ventilated after laparotomy. } \\
5.92 \text { A fumigatus: ciprofloxacin, prednisolone. }\end{array}$ & $\begin{array}{l}\text { Left lower lobe } \\
\text { infiltrate } \\
\mathrm{PO}_{2} 9 \cdot 2 \\
\text { No bronchoscopy }\end{array}$ & $\begin{array}{l}\text { Itraconazole } \\
\text { intravenously } \\
400 \mathrm{mg} / \text { day }(1 / 52)\end{array}$ & Died 1.52 \\
\hline 5 & $4 \cdot 92$ & $3 \cdot 8$ & 22 & $\begin{array}{l}\text { Dry cough, breathlessness, emphysema. } 11.92 \\
\text { A fumigatus: ciprofloxacin. }\end{array}$ & $\begin{array}{l}\text { Hyperinflation } \\
\mathrm{PO}_{2} 11 \cdot 2 \\
\text { No plaques }\end{array}$ & $\begin{array}{l}\text { Intraconazole elixir } \\
400 \mathrm{mg} / \text { day }(2 / 12)\end{array}$ & $\begin{array}{l}\text { Well } \\
\text { Renal aspergilloma }\end{array}$ \\
\hline 6 & $12 \cdot 92$ & $4 \cdot 4$ & 48 & $\begin{array}{l}\text { Fevers, breathlessness, cryptosporidiosis, } \\
\text { diarrhoea, ARSC on ERCP. CMV colitis. } \\
1.93 \text { A fumigatus: foscarnet, amphotericin. }\end{array}$ & $\begin{array}{l}\text { Diffuse infiltrate } \\
\mathrm{PO}_{2} 7 \cdot 0 \\
\text { Aspergillus plaques }\end{array}$ & $\begin{array}{l}\text { Amphotericin B } \\
1 \mathrm{mg} / \mathrm{kg} / \text { day }(2 / 52)\end{array}$ & $\begin{array}{l}\text { Died 2/52: multisystem } \\
\text { failure }\end{array}$ \\
\hline 7 & 1.93 & $4 \cdot 1$ & 12 & $\begin{array}{l}\text { Generalised malaise; CMV retinitis and } \\
\text { pneumonitis. } 1.93 \text { A fumigatus and Exophiala } \\
\text { dermatitides: dapsone, foscarnet. }\end{array}$ & $\begin{array}{l}\text { Aspergilloma right } \\
\text { upper lobe } \\
\mathrm{PO}_{2} 14 \cdot 1 \\
\text { No plaques }\end{array}$ & $\begin{array}{l}\text { Itraconazole tablet } \\
400 \mathrm{mg} / \text { day } 2 / 12\end{array}$ & Well \\
\hline 8 & $4 \cdot 92$ & $4 \cdot 1$ & 18 & $\begin{array}{l}\text { Fevers, dry cough, breathlessness, CMV/ } \\
\text { pneumonitis/colitis. } 2 \cdot 93 \text { A fumigatus: } \\
\text { ampicillin, metronidazole, cefuroxime, } \\
\text { amphotericin, ganciclovir }\end{array}$ & $\begin{array}{l}\text { Widespread bilateral } \\
\text { reticulo/nodular } \\
\text { shadowing } \\
\mathrm{PO}_{2} 8 \cdot 2 \\
\mathrm{No} \text { plaques }\end{array}$ & $\begin{array}{l}\text { Amphotericin B } \\
1 \mathrm{mg} / \mathrm{kg} / \text { day IV } \\
(3 / 52)\end{array}$ & $\begin{array}{l}\text { End stage disease: } \\
\text { unwell }\end{array}$ \\
\hline 9 & $1 \cdot 92$ & $1 \cdot 8$ & 4 & $\begin{array}{l}\text { Fevers, productive cough, breathlessness; } \\
\text { microsporidial diarrhoea, ARSC on ERCP- } \\
\text { treatment antibiotics. } 2.93 \text { A fumigatus/flavous: } \\
\text { ciprofloxacin, co-trimoxazole. }\end{array}$ & $\begin{array}{l}\text { Normal } \\
\mathrm{PO}_{2} 7 \cdot 4 \\
\mathrm{No} \text { bronchoscopy }\end{array}$ & $\begin{array}{l}\text { Itraconazole elixir } \\
\quad 400 \mathrm{mg} / \text { day }(3 / 52)\end{array}$ & $\begin{array}{l}\text { Died 4/52: multisystem } \\
\text { failure }\end{array}$ \\
\hline 10 & 11.92 & 0.4 & 40 & $\begin{array}{l}\text { Fevers, dry cough. Kaposi's sarcoma-treatment } \\
\text { razoxane and radiotherapy. } 3.93 \text { A fumigatus: } \\
\text { co-trimoxazole. }\end{array}$ & $\begin{array}{l}\text { Normal } \\
\mathrm{PO}_{2} 12 \cdot 5 \\
\text { No bronchoscopy }\end{array}$ & $\begin{array}{l}\text { Itraconazole elixir } \\
400 \mathrm{mg} / \text { day }(4 / 52)\end{array}$ & $\begin{array}{l}\text { Died 4/52: multisystem } \\
\text { failure }\end{array}$ \\
\hline 11 & $12 \cdot 93$ & $0 \cdot 2$ & 1 & $\begin{array}{l}\text { Fevers, dry cough, breathlessness, Kaposi's } \\
\text { sarcoma of skin and lung. Vincristine } 1 \mathrm{mg} \text {, } \\
\text { bleomycin } 15 \mathrm{mg} .1 .93 \text { A fumigatus: amoxycillin. }\end{array}$ & $\begin{array}{l}\text { Kaposi's sarcoma } \\
\text { nodules on lung } \\
\mathrm{PO}_{2} 13.0 \\
\text { No plaques }\end{array}$ & $\begin{array}{l}\text { Itraconazole tablet } \\
\quad 400 \mathrm{mg} / \text { day }(4 / 52)\end{array}$ & $\begin{array}{l}\text { Died 5/52: end stage } \\
\text { HIV disease }\end{array}$ \\
\hline
\end{tabular}

ARSC $=$ AIDS related sclerosing cholangitis; ERCP $=$ endoscopic retrograde cholangiopancreatogram.

toothbrush and thoroughly rinsing with water. Sputum was obtained by inhalation of 20-30 $\mathrm{ml}$ of $3 \%$ physiological saline through an ultrasonic nebuliser (De Vilbiss, Feltham, Middlesex). Gentle chest percussion was used when necessary and two sputum specimens were promptly taken to the laboratory. Bronchoalveolar lavage specimens were taken from the right middle lobe bronchus or alternatively the lobe with radiological abnormality. In those patients with abnormal white plaques in the bronchial tree, biopsy specimens were taken for culture and histological assessment to confirm the presence of fungal hyphae.

Standard mycological culture techniques were used to identify Aspergillus species. Samples of bronchial lavage and sputum were mixed with an equal volume of Sputasol (Oxoid) for 15 minutes at $37^{\circ} \mathrm{C}$ with regular mixing, after which the sample was centrifuged at $3000 \mathrm{rpm}$ for 10 minutes. The supernatant fluid was discarded and $25 \mathrm{ml}$ of the deposit was cultured on Sabouraud's dextrose agar plates with and without chloramphenicol for up to eight weeks at $30^{\circ} \mathrm{C}$ and $37^{\circ} \mathrm{C}$. The presence of fungi in the medium was identified using standard KOH/Parker's blue ink solution. All patients had a heavy growth of Aspergillus fumigatus. Initial positive induced sputa were confirmed either by subsequent bronchoalveolar lavage or a second induced sputum before inclusion in this report.
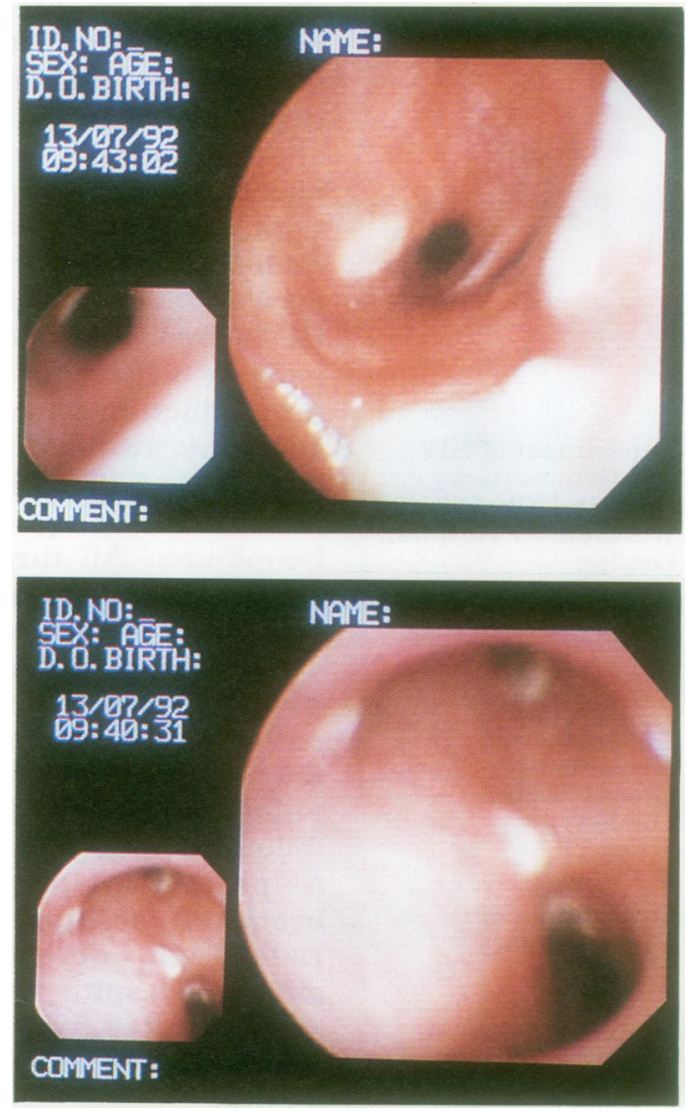

Figure 1(A) $(B)$ White raised plaques seen in trachea mainstem and segmental bronchi. This appearance is highly suggestive of tracheo-bronchial aspergillosis which can be confirmed by brushings and biopsy. 
Figure 2 Pulmonary aspergilloma. (A) Pre-treatment radiograph: aspergilloma; right upper zone consolidation. (B) Post-treatment radiograph; partial resolution of aspergilloma. (C) Radiograph showing recurrence of pulmonary aspergilloma, two month after stopping antifungal treatment. Left mid-zone consolidation has developed.
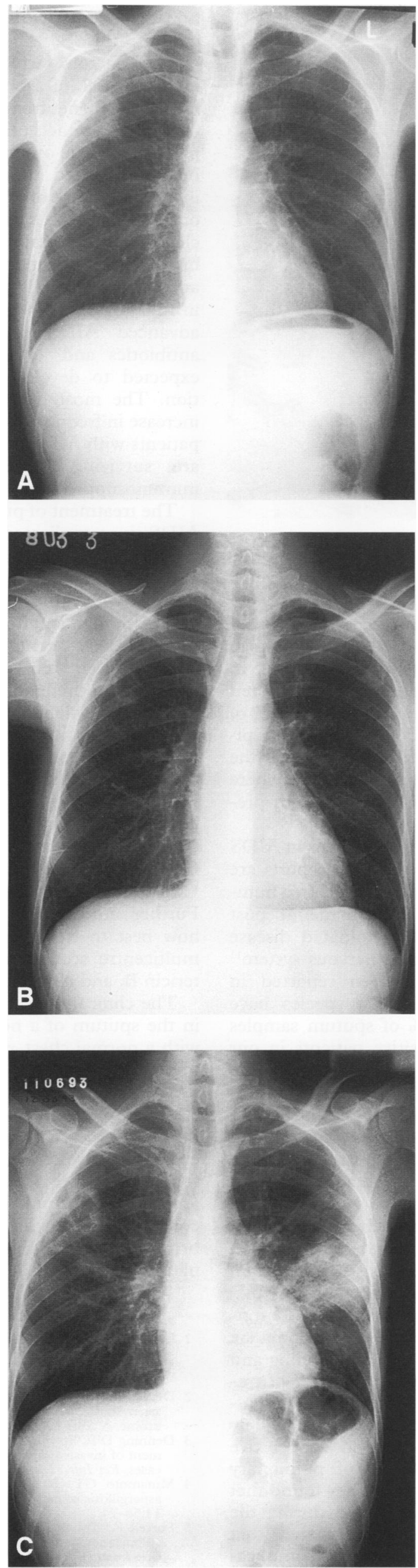

Results (table)

Between May 1992 and March 1993 Aspergillus sp were cultured from 10 of a total of 536 sputum induction samples and eight of 182 broncholoalveolar lavage samples obtained from HIV seropositive patients with respiratory symptoms. By contrast, between January 1985 and April 1992, only one sputum sample was positive for Aspergillus from a total of 1270 samples analysed (case 3).

Patients underwent sputum induction because of non-specific symptoms of nonproductive cough, breathlessness, and fever, with hypoxia being present in half the cases (table). Two patients had a normal chest $x$ ray picture and a further patient had only hyperinflated lung fields at presentation. The other patients had diffuse infiltration of the lungs and one patient had a cavitating aspergilloma (table).

Pulmonary aspergillosis was only found in those with advanced HIV infection after AIDS had been diagnosed (median seven months, range one to 26 months). The CD4 count was less than $50 \mathrm{~mm}^{-3}$ in 10 patients at the time of diagnosis. In the eleventh patient the CD4 count was $242 \mathrm{~mm}^{-3}$, although lymphoma had recently been diagnosed.

Neutropenia (neutrophil count of $0.5 \times$ $10^{9}$ per litre or less) was a likely contributing factor in four of 11 patients and was associated with chemotherapy for Kaposi's sarcoma in three. Broad spectrum antibiotics were prescribed in eight patients, three of whom were neutropenic. Four patients had cytomegalovirus affecting the colon, lung, or oesophagus. One patient was known to have smoked marijuana regularly (table).

Bronchoscopy was not performed in two of the three who had a normal chest $x$ ray picture and who were not clinically seriously ill nor in a third terminally ill patient with high grade lymphoma (case 4). Bronchoscopy in the other eight patients who had an abnormal chest $x$ ray picture revealed tracheobronchial Aspergillus plaques in three (fig 1). A heavy growth of Aspergillus was obtained from bronchoalveolar lavage specimens in all eight cases.

All patients were treated with antifungal drugs, two with amphotericin B and nine with itraconazole. In only one of the seven patients who died within six weeks was Aspergillus not eradicated from the sputum samples, although in this patient tracheobronchial Aspergillus plaques substantially regressed after three weeks of intravenous itraconazole. At the time of writing, two patients have survived for more than one year, one with negative sputum cultures for Aspergillus. One initially presented with an aspergilloma of the lung (fig 2) and a second patient (case 5) without bronchoscopic evidence of Aspergillus plaques developed a renal aspergilloma after six months of follow up (fig 3).

Death in eight of the 11 patients was expected because of complications of advanced HIV disease and one necropsy confirmed the presence of widespread sepsis and extensive pulmonary aspergillosis. 
Figure 3 Renal biopsy specimen. Area of necrosis showing aspergillus hyphae with septations, vesicular swellings, and dichotomous branching (periodic acidSchiff).

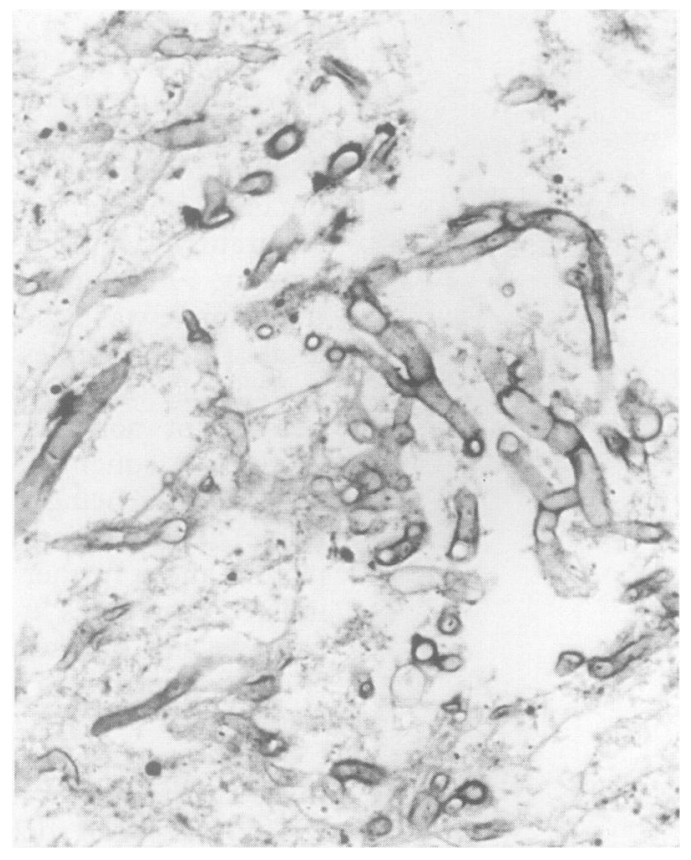

\section{Discussion}

Aspergillus is a ubiquitous fungal organism of which several hundred species are known to exist, although only a few cause disease in people. The most commonly encountered species is Aspergillus fumigatus. The portal of entry for infection is predominantly the respiratory tract where Aspergillus may colonise the bronchi or lung cavities, particularly where parenchymal damage has been caused by previous infections.

No case of pulmonary aspergillosis in AIDS has been reported in Britain, but reports are now being published elsewhere. ${ }^{128}$ In a number the diagnosis has been made at post mortem examination. ${ }^{9}$ Disseminated disease affecting the heart, ${ }^{10}$ central nervous system ${ }^{11}$ and pancreas $^{12}$ has also been reported in patients with AIDS. Candida species have been cultured from $10 \%$ of sputum samples taken from HIV seropositive patients in our unit over the past seven years, while Aspergillus species were only cultured in 11, 10 in the past 12 months. The temporal clustering of these patients and the finding of a heavy growth of Aspergillus repeatedly in these patients implies that these organisms are an important pathogen. This was confirmed in three cases with tracheobronchial plaques and in a fourth patient with a lung aspergilloma. A further patient with Aspergillus in his sputum on presentation, with a normal chest $x$ ray picture and no Aspergillus plaques at bronchoscopy, developed a renal aspergilloma six months later. A recent study by Denning and colleagues showed a similar incidence of tracheobronchial plaques in 12 patients with pulmonary aspergillosis, two of whom had widely disseminated disease. A French cooperative study has reported 33 cases of pulmonary aspergillosis from 17 centres. They found that $91 \%$ of the cases were reported during the preceding three years and suggested that Aspergillus infection is an emerging complica- tion in patients with AIDS. ${ }^{1}$ Our experience confirms this.

The factors which predispose to an increased risk of aspergillosis remain controversial. Both neutropenia and administration of steroids are accepted risk factors and were present in some of our patients. ${ }^{1314}$ It has also been suggested that smoking marijuana increases the risk of inhaling spores and one of our patients was a regular user. ${ }^{215}$ It is not clear how important the concurrent use of broad spectrum antibiotics in eight patients and the presence of cytomegalovirus infection in four may have been. ${ }^{16}$ Many patients with advanced AIDS require broad spectrum antibiotics and at least a third would be expected to develop cytomegalovirus infection. The most likely reason for the recent increase in frequency of Aspergillus infection in patients with AIDS in our unit is that patients are surviving longer with more severe immunosuppression.

The treatment of pulmonary aspergillosis in AIDS is complicated both because of the uncertainty that this fungus is a pathogen in all cases and because patients are often seriously ill with multisystem failure at presentation. Although amphotericin B is probably the most effective agent, it is extremely toxic to the kidneys and must be given intravenously. ${ }^{12}$ It would be preferable to have an oral agent and itraconazole is active against Aspergillus in vitro. Its clinical effectiveness is unclear, perhaps because of the poor absorption of the drug which has been reported to occur in HIV seropositive patients. ${ }^{1718}$ This may be improved using itraconazole solution (Abstract presented at the International Congress of Antimicrobial Agents and Chemotherapy, Anheim, California, 1992). Further advances in our understanding of how best to treat such patients will require multicentre studies of itraconazole, amphotericin $\mathrm{B}$, and newer antifungal agents.

The clinical relevance of finding Aspergillus in the sputum of a non-HIV infected person with a normal chest $x$ ray picture depends on the clinical setting, particularly the presence of neutropenia. ${ }^{6}$ In the context of HIV seropositive patients, Aspergillus in the sputum in two successive samples requires further evaluation, which should include bronchoscopy. We feel that early treatment with amphotericin B or itraconazole should be considered, even in those with a normal bronchoscopy, as this may prevent dissemination.

1 Lortholary O, Meyohas MC, DuPont B, et al. Invasive aspergillosis in patients with Acquired Immuno1993;95:177-87.

2 Denning DW, Follansbee SE, Scolaro M, et al. Pulmonary aspergillosis in the acquired immunodeficiency syndrome. $N$ Engl f Med 1991;324:654-62.

3 Denning DW, Stevens DA. Antifungal and surgical treatment of invasive aspergillosis: review of 2,121 published ment of invasive aspergillosis: review of

4 Minamoto GY, Barlam TF, Vander Els NJ. Invasive

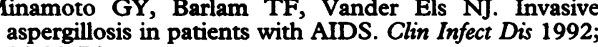
14:66-74.

5 Pursell K, Telzak EE, Armstrong D. Aspergillus species colonization and invasive disease in patients with AIDS Clin Infect Dis 1992;14:141-8. 
6 Cohen J. Clinical manifestations and management of aspergillosis in the compromised patient. In: Warnock $\mathrm{DW}$, Richardson MD, eds. Fungal infection in the compromised patient. New York: John Wiley and Sons, 1991: mised patien

7 Asnis DS, Chitkara RK, Jacobson M, Goldstein JA. Invasive aspergillosis: an unusual manifestation of AIDS. NY State f Med 1988;12:653-5.

8 Singh N, Yu VL, Rihs JD. Invasive aspergillosis in AIDS. South Med 7 1991;84:822-7.

9 Niedt GW, Schinella RA. Acquired immunodeficiency syndrome: clinicopathologic study of 56 autopsies. Arch Pathol Lab Med 1985;109:727-34.

10 Henochowicz S, Musafa M, Lawrinson WE, Pistole $M$, Lindsay J. Cardiac aspergillosis in acquired immune deficiency syndrome. Am $f$ Cardiol 1985;55: immune $1239-40$.

11 Woods GL, Goldsmith JC. Aspergillus infection in the central nervous system in patients with acquired immunodeficiency syndrome. Arch Neurol 1990;47: $181-4$.

12 Bhatt B, Cappell MS. A peripancreatic abscess containing
Aspergillus in a patient with the acquired immune deficiency syndrome. $A m \mathcal{F}$ Gastroenterol 1990;85:1200.

13 Schwartz RS, Mackintosh FR, Schrier SL Greent. PI

Multivariate analysis of factors associated with invasive fungal disease during remission induction therapy for acute myelogenous leukaemia. Cancer 1984;53:411-9.

14 Schaffner A. Acquired immunodeficiency syndrome: is disseminated aspergillosis predictive of underlying cellular immunodeficiency? I Infect Dis 1984;149:822-9.

15 Hamadeh R, Ardehali A, Locksley RM, York MK. Fatal aspergillosis associated with smoking contaminated matrow transplant recipient. Chest 1988;94:432-3.

16 Rand $\mathrm{KH}$, Pollard RB, Merigan TC. Increased pulmonary superinfections in cardiac-transplant patients undergoing primary cytomegalovirus infection. $N$ Engl $f$ Med ing primary cyto

17 Denning DW, Tucker R, Hanson LH, Stevens DA Treatment of invasive aspergillosis with itraconazole. $A m$ f Med 1989;86:791-800.

18 Dupont B. Itraconazole therapy in aspergillosis: study in 49 patients. F Am Acad Dermatol 1990;23:607-14. 